\title{
Sustainability Management for Reducing the Health Hazards in the Indoor Swimming Pools of UAE
}

\author{
Jolly Jacob $^{1} \&$ Jacob Cherian ${ }^{2}$ \\ ${ }^{1}$ Department of Applied Sciences, College of Arts and Sciences, Abu Dhabi University, Abu Dhabi, UAE \\ ${ }^{2}$ Department of Management, College of Business Administration, Abu Dhabi University, Abu Dhabi, UAE \\ Correspondence: Jolly Jacob, Department of Applied Sciences, College of Arts and Sciences, Abu Dhabi \\ University Abu Dhabi, UAE. E-mail: jolly.jacob@adu.ac.ae
}

Received: January 3, $2015 \quad$ Accepted: February 2, $2015 \quad$ Online Published: May 15, 2015
doi:10.5539/ass.v11n15p124
URL: http://dx.doi.org/10.5539/ass.v11n15p124

\begin{abstract}
The rapid development of various leisure and public pools in the 20th century has led to increased human exposure to chlorinated products. It has been observed that swimmers and pool workers, who are in regular contact with chlorinated indoor pool waters showed an increased risk of respiratory and allergic diseases. Various studies have reported that by-products of the chlorine based disinfectant used for the purpose of water purification can trigger allergic sensitization, thereby affecting the epithelial barriers and increasing the permeability of the allergens. With the ever increasing popularity of indoor swimming pool and recreational water activities, it is imperative to evaluate the impact of chlorine-based disinfectants and its oxidants on human health and their possible association with widespread allergic diseases. This paper reviews the existing literature and empirical studies conducted with regards to the human exposure to the harmful chemicals and by-products of chlorine-based disinfectants, especially in an indoor swimming pool setting and its association with the development of allergic and respiratory disorders.
\end{abstract}

Keywords: allergy, health hazard, Chlorine, indoor pool, respiratory disease

\section{Introduction}

Chlorination of water is closely associated with hygiene, and it is apparently one of the biggest developments of the 20th century in the field of public health. Waterborne illnesses such as cholera or dysentery, typhoid fever, have been virtually eradicated in the developed nations with the help of regular water chlorination, which has in turn contributed in increasing the longevity of humankind. Whether it is sanitization of recreational or drinking water, cleaning and disinfection of the floors and other surfaces in the food industry, use of chlorine-based disinfectants has become quite prevalent lately. Easy to use, low price, deodorizing, residual protection, and consistent sterilizer action against the broad range of microorganisms are some of the greatest advantages of chlorine (Rutala \& Weber, 1997; Ewart, 2001; Shulaw \& Bowman, 2001). Although chlorine is a commonly used disinfectant for both recreational as well as drinking water, it has a couple of disadvantages/drawbacks as well. Thus, the present study reviews the empirical evidence related to the risk of developing allergic or respiratory diseases due to the exposure to chlorinated water in the indoor swimming pools. To the best of researcher's knowledge, this is the first review to evaluate and document the health risks associated with chlorination of indoor pool water with reference to UAE. This paper also describes and reviews the process through which these chemicals and DBPs could cause allergic sensitization and recommends better pool management and safety measures.

\section{Background}

In the past few decades, a lot of studies from the medical perspective have focused on health risks associated with swimming in indoor pools due to the direct exposure to these disinfectants, chemicals and by-products of water disinfectants known as 'Disinfection Byproducts (DBPs)' (Kim, Shim, \& Lee, 2002). Out of the numerous byproducts that have been identified as common irritants are trihalomethane and chloramines (WHO, 2004). Various case studies conducted lately have found that certain high of level of chlorine in the indoor pool water can cause considerable health risks to the swimmers as well as pool workers; exposure to chlorine could lead to adverse health effects such as coughing, shortness of breath, irritable throat, and other respiratory problems 
(Nievas et al., 2008; Bonetto et al., 2006). Some of the other studies have also observed that continuous exposure to chlorine and DBPs could cause throat, nasal, skin and eye irritations (Basler et al., 2000; Jacobs et al., 2007; Le'vesque et al., 2006). Furthermore, it is evident that risk of allergy and increased permeability of lung epithelium leading to the risk of asthma is associated with the practice of swimming in the indoor pools (Carbonnelle et al., 2001; Carbonnelle et al., 2002; Thickett et al., 2002; Nemery, Hoet, \& Nowak, 2002; Bernard et al., 2003; Bernard et al., 2006), although these suppositions have not been confirmed by epidemiological studies (Font-Ribera et al., 2009; Ferrari et al., 2011; Voisin et al., 2010).

However, recently it was discovered that one of the DBPs, i.e. the trihalomethanes (THM) are potent carcinogens; thus, leading to a considerable amount of research works so as to evaluate the extent of exposure to chlorinated water and its associated carcinogenic risks. Epidemiological studies showed that there could be a possible increase in the risk of bladder cancer due to chronic exposure to chlorination products (CPs) either through bathing or drinking water (Villanueva et al., 2006; Villanueva et al., 2003), although regulatory bodies and scientists unanimously agree that the risk of cancer due to the exposure to CPs is far less when compared to the risks associated with inappropriate disinfections (WHO, 2000; WHO, 2006). The past studies of Bernard (2007) and Weng et al. (2011) showed that the effect of $\mathrm{NCl} 3$ affects respiratory system and eyes of human tissue. Moreover, the recent studies have identified that prevalence of respiratory and ocular irritation were observed among the pool workers and lifeguards, as they were heavily exposed to NCl3 (Fantuzzi et al., 2010; Dang et al., 2010). Moreover, the majority of pool workers had various symptoms like itchy eyes $(44.4 \%)$, cold (65.4\%), sneezing (52.6\%), and asthma (7.5\%) (Fantuzzi et al., 2010). NCl3 could easily be converted from a liquid form to gaseous state in chlorinated pool water, since it is an extremely volatile element. Thus, it is extremely vital that the pool operators must be well-informed and aware of the dynamic behaviour of this volatile compound $(\mathrm{NCl} 3)$ in order to maintain safety in the indoor pool environment.

\section{Chlorination of Swimming Pools}

The hotels all around the world use chemicals to clean the pool and air conditioner to persist the deadly bacteria in water and other. Some use liquid form of chlorine, sodium hypochlorite or calcium hypochlorite solution. However, this chlorine and other chemicals not only kill the disease-causing bacteria, but also various other harmful side effects are being caused for the individuals who use them. Firstly, the level of chlorine concentration in water needs to be carefully regulated, because it is a non-specific biocide. Secondly, when chlorine mixes with organic contaminants in the water, it turns into harmful byproducts that could be easily absorbed in the human body through skin, ingestion, and inhalation (Kogevinas \& Villanueva, 2010; Richardson, et al., 2010). The other forms of disinfectants like UV rays and ozone radiation killing the micro-organism seems to be ineffective, as these do not tend to continue to purify the water. Thus, bromine or chlorine is mixed continuously while treating the water. Generally, bromine in the liquid form is not used as disinfectant, rather sodium bromide and hypochlorite (sodium bromide's oxidant) is commonly used for water purification. However, in the outdoor swimming pools; the commonly used disinfectant is bromine, where the residues are actively destroyed by the sunlight. The selection of disinfectant is largely based on the situation, environmental conditions, ease of handling, and managing the water treatment process.

The widely used water disinfectant process in the swimming pools is chlorination because it is cheap and effective in inactivating numerous bacteria within a short period of time. Again, chlorine reacts with various organic matters in the water, especially elements of human body fluids (urine and sweat) and generates DBPs in the pool water (Judd \& Black, 2000; Weisel et al., 2009). Since the discovery of DBPs, researchers have identified some of the most volatile by-products found in chlorinated pool water that includes monochloramine $(\mathrm{NH} 2 \mathrm{Cl})$, dichloramine $(\mathrm{NHCl})$, trichloramine $(\mathrm{NCl})$, dichlorobromomethane $(\mathrm{CHBrCl} 2)$, bromoform $(\mathrm{CHBr} 3)$, chloroform $(\mathrm{CHCl} 3)$, cyanogen chloride $(\mathrm{CNCl})$, dichloromethylamine $(\mathrm{CH} 3 \mathrm{NCl} 2)$ and dichloroacetonitrile (CNCHCl2) (Li \& Blatchley, 2007). According to the study of Weaver et al. (2009), all these DBPs were commonly found in the indoor pool water samples; however, their concentration highly varied. Trichloramine (i.e. $\mathrm{NCl} 3$ ) is often mistaken as chlorine due to its distinct odour, has been widely identified as one of the most common by-products of organic-N compound that includes creatinine, amino acids, urea and chlorination in the swimming pools (Fantuzzi et al., 2013).

\section{Methodology}

The present review adopted the qualitative data collection method to collect the empirical evidence related to the risk of developing allergic or respiratory diseases due to the exposure to chlorinated water in the indoor swimming pools. As the researcher had no clear vision about the study's outcome, the qualitative methodology and exploratory research was adopted, as it supported in gaining deeper subject knowledge about the risk of 
developing allergic or respiratory diseases due to the exposure to chlorinated water in the indoor swimming pools by searching of literature (Saunders et al., 2003). The secondary data was collected from several sources, and this quantitative data was collected from secondary data sources like textbooks, government resources, newspapers, websites, journals and other internet sources. Moreover, majority of these secondary data were collected from academic databases, in order to ensure the collected data's reliability; in the case of non-availability, peer reviewed journals, government database and newspaper articles from UAE were relied.

\section{Exposure to Chlorine in Indoor Swimming Pools}

\subsection{Levels of Exposure}

Every human being is exposed to DBPs either by hot showers and chlorine-based oxidant found in the air above the surface of pool water or the drinking water containing chlorine (Lin et al., 2000 ). The DBPs are heavily concentrated, which has the strongest oxidants that are being found in the pool environment; these oxides are monohloramine, dichloramine in the aerosols, hypochlorous acid and trichloramine found in the gaseous form. Thus, the level of concentration of these oxidants greatly varies and is subjected to numerous factors which include air-temperature, level of aerosols sprayed, number of swimmers in the pool, and various physicochemical variables associated with the dose of chlorine (Lantagne et al., 2010). Various recent studies focused on the assessment of the quality of air in indoor pool environment and are mostly based in European nations (Belgium, France, Netherlands and Germany) (WHO, 2011). According to the studies of Bernard et al., 2003; Jacobs, Spaan et al., 2007; Lantagne et al., 2008, it was observed that, the average level of concentration of trichloramine in the indoor pool environment at a height of $1.5 \mathrm{~m}$ was found to be fluctuating between $300 \mu \mathrm{g} / \mathrm{m} 3$ and $500 \mu \mathrm{g} / \mathrm{m} 3$, and the extreme values observed were recorded as $2,000 \mu \mathrm{g} / \mathrm{m} 3$.

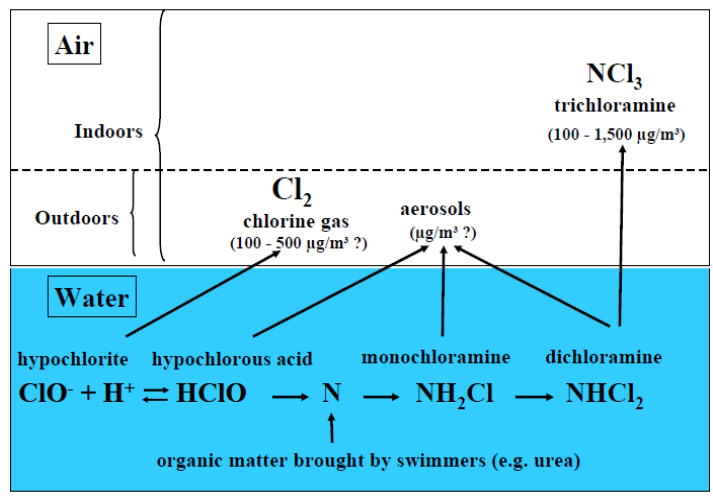

Figure 1. Key chlorine-based oxidants in chlorinated indoor as well as outdoor water and air (Bernard, 2007)

Studies have evaluated the exposure of DBPs level through environmental and biological monitoring. From the study findings, it was evident that the trihalomethanes (THMs) concentration caused DBPs. Swimming pool workers and swimmers from different areas experienced different THM exposure levels in which the alveolar air samples were subjected to $28.5 \pm 20.2 \mu \mathrm{g} / \mathrm{m} 3 \mathrm{~g} / \mathrm{m} 3$. However, the individuals working in cafe areas experienced $17.6 \pm 12.1 \mu \mathrm{g} / \mathrm{m} 3$ and in offices, environments faced $14.4 \pm 12.0 \mu \mathrm{g} / \mathrm{m} 3$ and the least exposure were experienced in engine rooms, which was $13.6 \pm 4.4 \mu \mathrm{g} / \mathrm{m} 3$. Thus the prevalence of respiratory, ocular irritative and cutaneous symptoms was mainly experienced by trainers and lifeguards in the swimming pool workers (Fantuzzi, 2014 ). The other powerful pollutants which affects children, and adults are exposed in a swimming pool environment is trichloramine and average level of concentration of trichloramine both in the indoor and outdoor pool environment in Europe barely exceed the mark of $300 \mu \mathrm{g} / \mathrm{m} 3$ (Air quality guidelines for Europe, 2000). Besides trichloramine, there is numerous other CPs like chlorinated micro aerosols or chlorine in the gaseous form, which also acts as oxidants that can cause possible health risk for the swimmers and pool workers.

Due to the huge variation in the proportion between the body mass and surface area (which is much greater), children tend to absorb the greater amount of chlorinated products through their skin that are water-soluble such as trihalomethanes or chloroform. The volumes of these soluble CPs absorbed are usually much more than their body-weight. Furthermore, children tend to swallow or inhale larger amounts of water droplets that are contaminated with soluble chloramines and/or hypochlorous acid. Depending on the pattern of respiration, which could be either nasal or oral and size of the aerosols, these oxidants can possibly travel deep into the respiratory tract (Helenius \& Haahtela, 2000; Helenius, Lumme \& Haahtela, 2005). 


\section{Health Risks Associated with Chlorinated Water}

Human exposure to chlorine in an indoor swimming pool usually happens through inhalation of vapours or aerosol, cutaneous absorption and ingestion of pool water. Numerous factors are responsible for the amount of water ingested that includes the level of experience, age, gender and nature of activity. The study of Evans, Cantú , Bahymer et al. (2001) revealed that the average amount of water consumed is more amongst children (37 $\mathrm{ml})$ than it is in adults $(16 \mathrm{ml})$ and gender-wise more in men $(22 \mathrm{ml})$ than it is in women $(12 \mathrm{ml})$. Further, the recent report by Fantuzzi et al. (2013) proved that pool work and trainers exposed to $\mathrm{NCl} 3$ was more than $0.5 \mathrm{mg} / \mathrm{m}$ and had higher risks of various diseases like runny nose (95\%), red eyes (95\%), voice loss $(95 \%)$ and itchy eyes $(95 \%)$ than others. Thus, the prevalence of ocular and other respiratory symptoms was frequently experienced among these workers.

The report from The Regulation and Supervision Bureau (2014) stated that the residual chlorine ideal concentration was identified and currently in Abu-Dhabi, the chlorination is between 0.2 to $0.5 \mathrm{mg} / \mathrm{l}$, which might increase up to $1.00 \mathrm{mg} / 100 \mathrm{mg} / \mathrm{l}$ or even above, causes various health effects. For instance, the report from Gulfnews (2001) stated that the swimmers in Dubai had red eye due to the exposure of the chlorination water system. Moreover, the other report from Saberi (2012) proved that UAE people had heavy hair loss due to the exposure of chlorinated water.

Several studies were conducted to identify the effect of chlorine exposure in the indoor swimming pool. The study by Kogevinas et al. (2010) proved that the exposure of DBPs causes cancer, either if the individuals drink or swim in the swimming pool. As far as bathers are concerned, they inhale the air which is in contact with the surface of the water. The duration of exposure, the intensity and nature of activity are the factors responsible for the volume of air inhaled. The exposure through inhalation is basically with regards to the gaseous state of chlorine, either it could be vapour released by the pool water or aerosols which are induced due to the stirring of water or swimmer's splashes (Villanueva et al., 2007). The parts of the human body that are largely exposed to the chemical compounds in the pool water are eyes, mucous membranes, and skin. Although, there are three main factors such as the level of skin absorption and length of time in contact with water, the level of concentration of toxic/chemical compounds, and the temperature of water. Studies also showed that a lot of water disinfectants by-products can produce carcinogenic, neurotoxic, hepatotoxic, dysmetabolic and mutagenic (Meek et al., 2002).

DBPs, particularly to trichloramine, which is widely believed to be the most significant risk factor that causes irritation, who are occupationally exposed as well as the swimmers at indoor swimming pools (Erdinger et al., 2004; WHO, 2006 ; Jacobs et al., 2007; Cimitiere \& Laat, 2009; Fantuzzi et al., 2010 ). Higher microbial and hygiene indicators in the recreational waters are directly correlated to the increased health risk of the swimmers; hence, swimming pool waters are commonly examined for these indicators (Maida et al. 2008; Ferretti et al., 2013). The most common contributors of bacterial contamination in pool waters are floor and outlets around the pool, wet shower benches and sanitary facilities; these places are some of the most favourable areas for the growth of bacteria. Nonetheless, management of pool water is necessarily associated with the growth of bacteria within the pool water (Briancesco et al., 2010).

The epidemiological studies report (Thickett et al., 2002; Nemery et al., 2002; Lazarov et al., 2005; Levesque et al., 2006; Jacobs et al., 2007; Weisel et al., 2009) proved that both swimmers and the pool workers, who used indoor swimming pool were subjected to various respiratory risks, asthmatic conditions and skin diseases like contact dermatitis. Furthermore, couple of other studies have also reported hypersensitivity that immunological reaction in water is due to contact between hypochlorite present in the cleaning agent and urticaria in a chlorinated swimming pool (International Occupational Safety and Health Information Centre (CIS), 2009; United States Environmental Protection Agency (EPA) 2013). Another study reported that excessive or constant exposure to hypochlorite can lead to skin reactions and have been further described as delayed hypersensitivity or allergic contact dermatitis (Font-Ribeira et al., 2009). Studies have also shown that consumption of or exposure to CPs through drinking or recreational water can possibly induce asthma or cause irritation in the respiratory tract. Various sources such as swimmers and tap water contribute to numerous natural organic precursors' substances in swimming pool water, which includes particles of hair and skin, constituents of urine and perspiration, cosmetic and other personal care products. These precursors' substances tend to react with free chlorine to form various DBPs, which could either be organic or inorganic chloramines, organic compounds or haloacetonitriles; few of these are volatile in nature and can cause respiratory irritation (Li \& Blatchley, 2007). Several studies have shown that young and adult swimmers who are exposed to these chemicals, irritants, and DBPs have often reported incidents of asthma (McConnell et al., 2002; Medina-Ramón et al., 2005; Rumchev et al., 2004; Sherriff et al., 2005; Zock et al., 2007). 


\subsection{Health Risks for Swimmers and Pool Workers and Lifeguards}

The cities like Abu Dhabi, Dubai from UAE are famous for its luxury hotels and swimming pools. Even though there is an increasing portable demand for water in Abu Dhabi (Regulation \& Supervision Bureau, 2011 Annual reports), the custom of indoor swimming pools has also created curiosity from the therapeutic outlook. However, these probable pessimistic fitness effects have resulted in undeviating contact with DBPs and other chemicals, which are used as water disinfectants in these swimming pools (Kogevinas et al., 2010; Richardson et al., 2010). The disinfectant not only kills the bacteria in the water, but also causes harmful effects for both swimmers and pool works. The swimmers who are exposed to chlorine and other forms of disinfectant like trihalomethane and chloramines experience adverse health effects namely throat pain, gasping, shortness of breath, coughing (Almagro et al., 2008; Bonetto et al., 2006). Moreover, the eye, throat, skin and nasal frustration are also experienced by the swimmers who have chronic exposure and other DBPs in pool water (Basler et al., 2000; Jacobs et al., 2007; Le'vesque et al., 2006). Studies (Font-Ribera et al., 2009; Cassan et al., 2009; Lee, Ha, \& Zoh, 2009; Ferrari et al., 2011; Voisin et al., 2010) have shown that individuals with swimming habit have the risk of allergic reactions and asthma.

Further, the studies have proven that children exposed to chlorine from birth until first grade of primary schooling have the risk of childhood asthma (Bernard et al., 2003). The WHO (2006) reported that the workers in halogenated disinfection chlorinated pool water are frequently diagnosed with various harmful effects and acute illnesses and injury from the swimming pool. Even the indoor pool workers are subjected to various acute illnesses like irritated eye, nose and throat indications, as well as asthma, swimming pools (Thickett et al., 2002; Levesque et al., 2006; Jacobs et al., 2007; Hery et al., 1995; Kaydos-Daniels et al., 2008). This is because the works clean the pool in order to maintain the cleanliness; thus, they are exposed to chloramines, in particular trichloramine and other fundamental cleaning agent. In addition, due to cleaning process these workers are exposed to chemical reactions between amino-compounds and ammonia from swimmer's urine and sweat and chlorine (Nemery et al., 2002 WHO, 2006) However, the Bernard et al., (2006) and Helenius et al., (2002) proved that female lifeguards (28\%) were affected more when compared to male lifeguards (13.7\%). However, when compared to swimmers, the pool works are affected more as they are exposed to this chlorine and chlorinated products consistently.

\section{Allergic Reaction to Chlorination}

The development of allergies begins with sensitization to common allergens, where the allergens go past the polarized barrier of epithelial cells and interact with dendritic cells (antigen-presenting cells). Oxidants that are chlorine-based found in the air and water act as chemical ancillary that facilitate the disruption in the epithelial passage; thus, allows the allergens to enter, thereby intensifying the sensitization process. This is the mechanism through which the chlorinated pool water interacts and is associated with the development of asthma amongst children and other allergic diseases amongst recreational swimmers (Bernard et al., 2003, 2006; Zwick et al., 1990; Potts, 1996; Helenius et al., 2002; Helenius et al., 1998).

It has also been reported that continuous or extensive exposures to CPs may eventually damage the epithelial cells. Epithelial cells are known for the synthesis and secretion of numerous molecules that regulate the inflammatory/ antioxidant proteins, lipid mediators and the inflammatory or allergic responses that include chemokines/ascytokines; thus, damage to these cells could result in grave consequences (Takizawa, 2005). Few studies have also reported that the damage to these cells led to reduction of anti-inflammatory CC16 amongst young swimmers who during their early childhood used to attend the indoor swimming pool regularly (Bernard \& Nickmilder, 2006; Bernard et al., 2007; Lagerkvist et al., 2004).

The parts of the body affected due to the exposure to the CPs, depend solely on couple of reasons; first is the physiochemical characteristics of the chemicals such as the solubility in water and second one is the form in which these oxidants are present in the air gaseous state or in the form of aerosols. Trichloramine in the gaseous form is the most toxic element due to its insoluble property and causes disruption to distal airways (Carbonnelle et al., 2001; Carbonnelle et al., 2002; Lagerkvist et al., 2004), which could in turn cause restriction in the airflow and inflammation leading to the development of asthma (Tulic\& Hamid, 2003). Whereas, on the other hand, when other non-volatile oxidants such as chloramines or hypochlorite are inhaled in gaseous form or as aerosols enter in the nasal cavity along with water, thus disrupting the epithelial barrier present in the upper airways and making them highly prone to allergens (Weisel et al., 2009).

Figure (2) illustrates the mechanism of disruption of epithelial barriers caused due to chlorine-based oxidants and permeability of allergens and their interaction with immune-competent cells. Due to the potential characteristic of oxidization of CPs, apparently they become the strongest triggers that cause disruption to epithelial barriers; 
moreover, numerous other air pollutants (dust mites, pollens, etc.) also have the potential to compromise the epithelial effects and sometimes act in synergy with CPs, thereby further facilitating the allergic sensitization (Bonini et al., 2006).

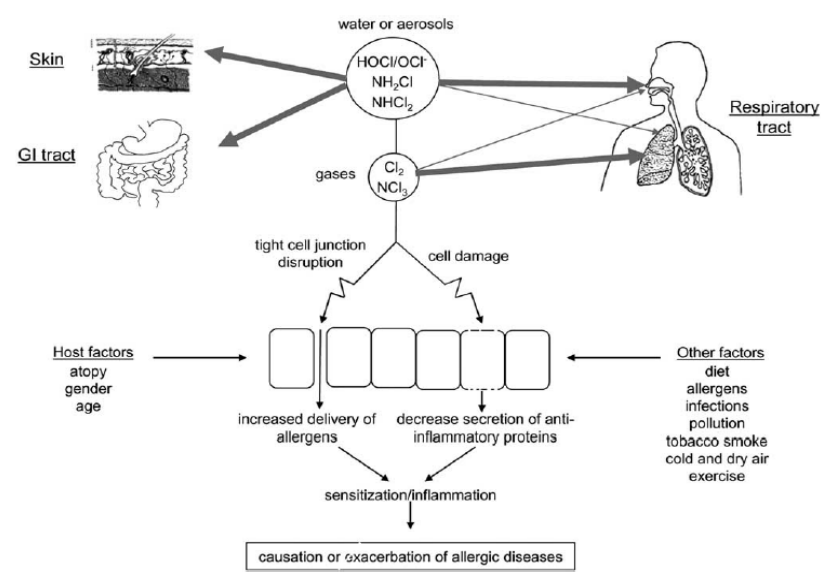

Figure 2. Disruption caused by chlorine-based oxidants to the epithelial barriers (Source: Bernard, 2007)

\section{Health Hazards due to Chlorinated Water in UAE}

In an article in The National, it was highlighted by Prof Walid El Shorbagy, the director of the water resources programme at UAE University, who said that "Chlorine has more by-products, which are more hazardous" (Malek, 2012). In another article in the same year, it was highlighted that experts had warned against the use of chemicals to treat swimming pools, which could possibly lead to asthma and bladder cancer. Thus, this section reviews the health hazards due to chlorinated water in UAE context.

Recent article Sankar (2009) reported that in Dubai pool, individuals developed infections and were fallen sick after swimming due to over use of cleaning agents which resulted in skin irritation and rashes. In addition, the article also reported that the immune system of children and pregnant women were affected. The article proposed that even though the maintenances of pools costfrom Dh500 to Dh600 to maintain a 100 cubic metre, it is essential to clean the pool twice or thrice a week, and the water need to be changed consistently.

The study by Rumaithi and Anouti (2014) examined human health's potential risk, particularly elderly and children infected by inhalation of aerosol. Even though UAE is famous for its shopping malls and exquisite cleanliness management, which are monitored and inspected routinely, still there is a prevalence of microbial risk. The study was conducted in Abu Dhabi (UAE) in which three shopping malls were selected randomly. The results indicated that there was a significant difference in the microbial profiles of shopping mall's ornamental water. Thus, the study concluded that, in order to ensure public safety at all times, the study emphasized the needs for maintenance have to be conducted timely for public health safety, and prioritized the importance of establishing proper guidelines for shopping mall's ornamental water within indoor malls in Abu Dhabi.

Similarly, the article published by Malek (2012) examined the side effects of using disinfectant in air-conditioning systems and Swimming pools in Dubai. The article stated that liquidated forms of chlorine and calcium hypochlorite solution or sodium hypochlorite were used as cleaning agents which caused harmful side effects. The report reported that lesser concentration of chlorine is ineffective which leaves Legionella pneumophila bacteria in water. This results in Legionnaires disease. However, the report stated even though chlorine dioxide is expensive; it must be used, as it is safer and better. In addition, majority of the people in Dubai used the powdered form of chlorine dioxide, which is known as Metoxide as it is more effective than traditional chlorine and other harmful by-products.

Likewise, the Kumar (2012)'s article reported that private residential pools in Dubai were infested with bacteria, which caused health risk for both swimmer and pool workers. The article also reported that chlorinated water caused gastro-intestinal infection, vaginal infections, and rashes in skins, stomach ailments, urinary tract and conjunctivitis. However, the article concluded that the pools need to be analyzed for bacteriological test, which is a cost effective method, i.e. it costs only Dh350 and there is need to create awareness on the same.

Likewise, the study by Aljanahi and Khan (2014) examined the prevalence of Cryptosporidium and Giardia in the school swimming pool. The study was conducted in Dubai (UAE). In the study, the immunofluorescence 
assay was used by the researcher to test the Cryptosporidium oocysts and Giardia cysts from the water sample, which was collected from five schools. The study adopted the membrane filtration technique to examine the total fecal coliform and the heterotrophic bacteria level in the water samples. From the study findings, it is evident that majority of the water sample either had Giardia cysts or Cryptosporidium oocysts, else both were also present. From the results, it was evident that the level of Cryptosporidium oocysts was identified to be 1-15 oocysts per liter, which is known to be as higher range than that of Giardia cysts, which were only 1-4 cysts per liter.

It is evident from the existing literature that chlorination of indoor swimming pool water leads to various health hazards, mainly respiratory and/or allergic diseases and causes gastro-intestinal infection, vaginal infections, and rashes in skins, stomach ailments, urinary tract, conjunctivitis and Legionnaires disease. There are numerous relevant empirical studies available to support this finding; however, they have mostly been conducted in America or in Europe. To the best of my knowledge, no study has been conducted so far in UAE to examine the level of exposure and health hazards related to the chlorination of indoor swimming pool water.

\section{Conclusion}

The review of various studies shows that chlorine is the most commonly used disinfectant to treat the public recreational water in order to make it clean and safe and reduce the risk of microbial infection. However, at the same time, it has also been noticed that use of chlorine in indoor swimming pools leads to contamination by volatile oxidants and aerosolized CPs, and most of these elements have been identified as respiratory irritants or allergens. Trihalomethanes out of all the DBPs have been found to have the highest concentration in the indoor pool water, although the level varies depending on several factors such as choice of disinfectant, and precursor material in the pool water. Trihalomethanes is also dispersed in the air at the surface of the pool water in gaseous phase and even for this, the level of concentration in the air varies depending on the factors such as temperature of the water and disturbance in the water created by swimmers. Trihalomethanes has also been highlighted as the most powerful DBP that has a positive association with increased risk of respiratory problems amongst swimmers and pool workers. Furthermore, it was observed that several studies had consistently reported that exposure to chlorine based disinfectant in the indoor swimming pool environment are associated with childhood asthma epidemic, especially in developed nations. The use of chlorine works as an ancillary causing an increased risk of atopic asthma, which means it is mainly responsible for the development of asthma (Von Mutius, 201). In addition, other risks include runny nose, red eyes, voice loss and itchy eyes (Fantuzzi et al., 2013). Thus, the prevalence ocular and other respiratory symptoms were frequently experienced among these workers also.

There are limited or no studies available that suggest the optimum pool management mechanism for reducing the risk of exposure to irritants. The current evidence did highlight the association between exposure to CPs in chlorinated indoor swimming pools and the onset of asthma amongst young and adult swimmers and pool workers in UAE; however, most of these observations are mostly suggestive and not conclusive. However, current studies are limited in terms of extending an exhaustive knowledge about the characteristics of DBPs, the level of concentration of DBPs in various indoor swimming pools, appropriate assessment of exposure to be respiratory irritants and characterization of respiratory problem or asthma caused due to chlorinated indoor swimming pools.

\section{Recommendation}

It is recommended that the key factors responsible for reduction of the exposure to oxidants are construction, maintenance and management of the swimming pool. Considering the growing interest in assessing the risk factors associated with the use of chlorine as disinfectant in indoor pool water; this paper recommends that as part of better pool management practices, public should be made aware of the hygienic practices (such as, limited use of cosmetic products or not urinating inside the pool) before they enter the swimming pool. Moreover, the poor indoor air quality issues can be addressed with preventive measures like improving air movement over the pool and increasing the air turnover rate which will reduce irritant levels in the air. Additionally, appropriate standards for regulating and monitoring the water and air quality should be reinforced to reduce the risk of human exposure to harmful chemicals used in the disinfectants. Furthermore, the existing literature available has largely been conducted in European nations, which limits the general applicability of the findings across geographical borders. Thus, future epidemiological and empirical studies need to focus on the assessment of exposure to chlorinated indoor pools and its impact on the health of swimmers and pool workers in UAE.

\section{References}

Aggazzotti, G., Fantuzzi, G., Righi, E., \& Predieri, G. (1995). Environmental and biological monitoring of 
chloroform in indoor swimming pools. Journal of Chromatography. A, 710(1), 181-190. http://dx.doi.org/ 10.1016/0021-9673(95)00432-M.

Air quality guidelines for Europe. (2000). In Air quality guidelines for Europe (2nd ed.). European Series $n^{\circ} 91$.WHO Regional publications

Al Rumaithi, F. S., \& Al Anouti, F. (2014). The Quality of Ornamental Water within Shopping Malls in the United Arab Emirates. Virology \& Mycology, 3, 132. http://dx.doi.org/10.4172/2161-0517.1000132.

Aljanahi, A., \& Khan, M. A. (2014). A Preliminary Assessment of the Occurrence of Cryptosporidium and Giardia in the School Swimming Pool Water in Dubai, United Arab Emirates. International Journal of Environmental Science and Development, 5(3), 303-308. http://dx.doi.org/10.7763/IJESD.2014.V5.497

Almagro Nievas, D., Acuña Castillo, R., Hernández Jerez, A., \& Robles Montes, A. (2008). [Investigation of an outbreak of acute respiratory illness due to exposure to chlorine gas in a public swimming pool]. Gaceta Sanitaria / S.E.S.P.A.S, 22(3), 287-290. Retrieved from http://www.ncbi.nlm.nih.gov/pubmed/18579056

Basler, R. S., Basler, G. C., Palmer, A. H., \& Garcia, M. A. (2000). Special skin symptoms seen in swimmers. Journal of the American Academy of Dermatology, 43(2 Pt 1), 299-305. http://dx.doi.org/10.1067/mjd.2000. 107495

Bernard, A. (2007). Chlorination products: emerging links with allergic diseases. Current Medicinal Chemistry, 14(16), 1771-1782. http://dx.doi.org/10.2174/092986707781058940

Bernard, A., \& Nickmilder, M. (2006). Respiratory health and baby swimming. Archives of Disease in Childhood, 91(7), 620-621. http://dx.doi.org 10.1136/adc.2006.097097

Bernard, A., Carbonnelle, S., de Burbure, C., Michel, O., \& Nickmilder, M. (2006). Chlorinated Pool Attendance, Atopy, and the Risk of Asthma during Childhood. Environmental Health Perspectives, 114(10), 1567-1573. http://dx.doi.org10.1289/ehp.8461

Bernard, A., Carbonnelle, S., Dumont, X., \& Nickmilder, M. (2007). Infant swimming practice, pulmonary epithelium integrity, and the risk of allergic and respiratory diseases later in childhood. Pediatrics, 119(6), 1095-1103. http://dx.doi.org/10.1542/peds.2006-3333

Bernard, A., Carbonnelle, S., Michel, O., Higuet, S., De Burbure, C., Buchet, J.-P., ... Doyle, I. (2003). Lung hyperpermeability and asthma prevalence in schoolchildren: unexpected associations with the attendance at indoor chlorinated swimming pools. Occupational and Environmental Medicine, 60(6), 385-394. Retrieved from http://www.pubmedcentral.nih.gov/articlerender.fcgi?artid=1740550\&tool=pmcentrez\&rendertype= abstract

Bernard, A., Carbonnelle, S., Nickmilder, M., \& de Burbure, C. (2005). Non-invasive biomarkers of pulmonary damage and inflammation: Application to children exposed to ozone and trichloramine. Toxicology and Applied Pharmacology, 206(2), 185-190. http://dx.doi.org/10.1016/j.taap.2004.10.022

Bonetto, G., Corradi, M., Carraro, S., Zanconato, S., Alinovi, R., Folesani, G., ... Baraldi, E. (2006). Longitudinal monitoring of lung injury in children after acute chlorine exposure in a swimming pool. American Journal of Respiratory and Critical Care Medicine, 174(5), 545-549. http://dx.doi.org/10.1164/ rccm.200509-1392OC

Bonini, S., Bonini, M., Bousquet, J., Brusasco, V., Canonica, G. W., Carlsen, K.-H., ... Vignola, A. M. (2006). Rhinitis and asthma in athletes: an ARIA document in collaboration with GA2LEN. Allergy, 61(6), 681-692. http://dx.doi.org/10.1111/j.1398-9995.2006.01080.x

Briancesco, R., Semproni, M., Libera, S. Della, Sdanganelli, M., \& Bonadonna, L. (2010). Non-tuberculous mycobacteria and microbial populations in drinking water distribution systems. Mycobacteria and Microrganisms in Water, 46(3), 254-258. http://dx.doi.org/10.4415/ANN

Carbonnelle, S., Buchet, J. P., Hermans, C., Doyle, I., \& Bernard, A. (2001). Increased lung epithelium permeability in children regularly attending chlorinated pools. Eur. Respir. J., 18(33), 186.

Carbonnelle, S., Francaux, M., Doyle, I., Dumont, X., de Burbure, C., Morel, G., ... Bernard, A. (2002). Changes in serum pneumoproteins caused by short-term exposures to nitrogen trichloride in indoor chlorinated swimming pools. Biomarkers: Biochemical Indicators of Exposure, Response, and Susceptibility to Chemicals, 7(6), 464-478. http://dx.doi.org/10.1080/13547500210166612

Cassan, D., Mercier, B., Castex, F., \& Rambaud, A. (2009). Effects of medium-pressure UV lamps radiation on water quality in a chlorinated indoor swimming pool. Chemosphere, 62(9), 1507-1513. 
http://dx.doi.org/10.1016/j.chemosphere.2005.06.006

Chu, H., \& Nieuwenhuijsen, N. J. (2002). Distribution and determinants of trihalomethane concentrations in indoor swimming pools. Occupational and Environmental Medicine, 59(4), 243-247. http://dx.doi.org/10.1136/oem.59.4.243

Cimitiere, N., \& De Laat, J. (2009). Henry's law constant of N,N-dichloromethylamine: application to the contamination of the atmosphere of indoor swimming pools. Chemosphere, 77, 465-470.

Dadswell, J. V. (1996). Managing swimming, spa, and other pools to prevent infection. Communicable Disease Report. CDR Review, 6(2), R37-40. http://dx.doi.org/8777444

Dang, B., Chen, L., Mueller, C., Dunn, K. H., Almaguer, D., Roberts, J. L., \& Otto, C. S. (2010). Ocular and respiratory symptoms among lifeguards at a hotel indoor waterpark resort. Journal of Occupational and Environmental Medicine / American College of Occupational and Environmental Medicine, 52(2), 207-213. http://dx.doi.org/10.1097/JOM.0b013e3181cf00d5

Erdinger, L., Kühn, K. P., Kirsch, F., Feldhues, R., Fröbel, T., Nohynek, B., \& Gabrio, T. (2004). Pathways of trihalomethane uptake in swimming pools. International Journal of Hygiene and Environmental Health, 207(6), 571-575. http://dx.doi.org/10.1078/1438-4639-00329

Evans, O., Cantú, R., Bahymer, T. D., Kryak, D. D., \& Dufour, A. P. (2001). A pilot study to determine the water volume ingested by recreational swimmers. In Paper presented to 2001 Annual Meeting of the Society for Risk Analysis. Seattle, Washington.

Ewart, S. (2001). Disinfectants and control of environmental contamination. In B. Smith (Ed.), Large Animal Internal Medicine: diseases of horses cattle, sheep and goats (3rd ed., pp. 1371-1380). St. Louis: Mosby.

Fantuzzi, G. (2014). Adipose Tissue and Adipokines in Health and Disease (p. 388). Springer Science \& Business. Retrieved from https://books.google.co.in/books?id=fYq4BAAAQBAJ\&dq=Fantuzzi+et+al.,+ 2010\&source $=$ gbs_navlinks_s

Fantuzzi, G., Righi, E., Predieri, G., Ceppelli, G., Gobba, F., \& Aggazzotti, G. (2001). Occupational exposure to trihalomethanes in indoor swimming pools. The Science of the Total Environment, 264(3), 257-265. http://dx.doi.org/11213196

Fantuzzi, G., Righi, E., Predieri, G., Giacobazzi, P., Mastroianni, K., \& Aggazzotti, G. (2010). Prevalence of ocular, respiratory and cutaneous symptoms in indoor swimming pool workers and exposure to disinfection by-products (DBPs). International Journal of Environmental Research and Public Health, 7(4), 1379-1391. http://dx.doi.org/10.3390/ijerph7041379

Fantuzzi, G., Righi, E., Predieri, G., Giacobazzi, P., Petra, B., \& Aggazzotti, G. (2013). Airborne trichloramine $(\mathrm{NCl}(3))$ levels and self-reported health symptoms in indoor swimming pool workers: dose-response relationships. Journal of Exposure Science \& Environmental Epidemiology, 23(1), 88-93. http://dx.doi.org/ $10.1038 /$ jes.2012.56

Ferrari, M., Schenk, K., Mantovani, W., Papadopoulou, C., Posenato, C., Ferrari, P., ... Tardivo, S. (2011). Attendance at chlorinated indoor pools and risk of asthma in adult recreational swimmers. Journal of Science and Medicine in Sport / Sports Medicine Australia, 14(3), 184-189. http://dx.doi.org/10.1016/j. jsams.2010.12.006

Ferretti, E., Fantuzzi, G., Romano Spica, V., Caroli, S., \& Bonadonna, L. (Eds.). (2013). Swimming Pool \& Spa. In Fifth International Conference. Rome: Fifth International Conference Swimming Pool \& Spa.

Font-Ribera, L., Kogevinas, M., Zock, J.-P., Nieuwenhuijsen, M. J., Heederik, D., \& Villanueva, C. M. (2009). Swimming pool attendance and risk of asthma and allergic symptoms in children. The European Respiratory Journal, 34(6), 1304-1310. http://dx.doi.org/10.1183/09031936.00180608

Gulfnews. (2001). Water treatment method may end swimmer red-eye. Retrieved January 12, 2015, from http://gulfnews.com/news/gulf/uae/general/water-treatment-method-may-end-swimmer-red-eye-1.411299

Helenius, I. J., Tikkanen, H. O., Sarna, S., \& Haahtela, T. (1998). Asthma and increased bronchial responsiveness in elite athletes: atopy and sport event as risk factors. The Journal of Allergy and Clinical Immunology, 101(5), 646-652. http://dx.doi.org/10.1016/S0091-6749(98)70173-3

Helenius, I., \& Haahtela, T. (2000). Allergy and asthma in elite summer sport athletes. The Journal of Allergy and Clinical Immunology, 106(3), 444-452. http://dx.doi.org/10.1067/mai.2000.107749 
Helenius, I., Lumme, A., \& Haahtela, T. (2005). Asthma, airway inflammation and treatment in elite athletes. Sports Medicine (Auckland, N.Z.), 35(7), 565-574. http://dx.doi.org/16026170

Helenius, I., Rytilä, P., Sarna, S., Lumme, A., Helenius, M., Remes, V., \& Haahtela, T. (2002). Effect of continuing or finishing high-level sports on airway inflammation, bronchial hyperresponsiveness, and asthma: a 5-year prospective follow-up study of 42 highly trained swimmers. The Journal of Allergy and Clinical Immunology, 109(6), 962-968. http://dx.doi.org/10.1067/mai.2002.124769

Hery, M., Hecht, G., Gerber, J., Gendre, J., Hubert, G., \& Rebuffaud, J. (1995). Exposure to chloramines in the atmosphere of indoor swimming pools. The Annals of Occupational Hygiene, 39(4), 427-439. http://dx.doi.org/10.1016/0003-4878(95)00013-5

Jacobs, J. H., Spaan, S., van Rooy, G. B. G. J., Meliefste, C., Zaat, V. A. C., Rooyackers, J. M., \& Heederik, D. (2007). Exposure to trichloramine and respiratory symptoms in indoor swimming pool workers. The European Respiratory Journal, 29(4), 690-698. http://dx.doi.org/10.1183/09031936.00024706

Judd, S., \& Black, S. H. (2000). Disinfection by-product formation in swimming pool waters: a simple mass balance. Water Research, 34(5), 1611-1619. http://dx.doi.org/10.1016/S0043-1354(99)00316-4

Kaydos-Daniels, S. C., Beach, M. J., Shwe, T., Magri, J., \& Bixler, D. (2008). Health effects associated with indoor swimming pools: a suspected toxic chloramine exposure. Public Health, 122(2), 195-200. http://dx.doi.org/10.1016/j.puhe.2007.06.011

Kim, H., Shim, J., \& Lee, S. (2002). Formation of disinfection by-products in chlorinated swimming pool water. Chemosphere, 46(1), 123-130. http://dx.doi.org/10.1016/S0045-6535(00)00581-6

Kogevinas, M., Villanueva, C. M., Font-Ribera, L., Liviac, D., Bustamante, M., Espinoza, F., ... Marcos, R. (2010). Genotoxic effects in swimmers exposed to disinfection by-products in indoor swimming pools. Environmental Health Perspectives, 118(11), 1531-1537. http://dx.doi.org/10.1289/ehp.1001959

Kumar, A. (2012). Dubai pools infested with bacteria. Retrieved January 12, 2015 from http://gulfnews.com/ news/gulf/uae/health/dubai-pools-infested-with-bacteria-1.1041469.

Lagerkvist, B. J., Bernard, A., Blomberg, A., Bergstrom, E., Forsberg, B., Holmstrom, K., ... Nordberg, G. (2004). Pulmonary epithelial integrity in children: relationship to ambient ozone exposure and swimming pool attendance. Environmental Health Perspectives, 112(17), 1768-1771. http://dx.doi.org/10.1289/ ehp.7027

Lantagne, D. S., Blount, B. C., Cardinali, F., \& Quick, R. (2008). Disinfection by-product formation and mitigation strategies in point-of-use chlorination of turbid and non-turbid waters in western Kenya. Journal of Water and Health, 6(1), 67-82. http://dx.doi.org/10.2166/wh.2007.013

Lantagne, D. S., Cardinali, F., \& Blount, B. C. (2010). Disinfection by-product formation and mitigation strategies in point-of-use chlorination with sodium dichloroisocyanurate in Tanzania. The American Journal of Tropical Medicine and Hygiene, 83(1), 135-143. http://dx.doi.org/10.4269/ajtmh.2010.09-0431

Lazarov, A., Nevo, K., Pardo, A., \& Froom, P. (2005). Self-reported skin disease in hydrotherapists working in swimming pools. Contact Dermatitis, 53(6), 327-331. http://dx.doi.org/10.1111/j.0105-1873.2005.00699.x

Lee, J., Ha, K.-T., \& Zoh, K.-D. (2009). Characteristics of trihalomethane (THM) production and associated health risk assessment in swimming pool waters treated with different disinfection methods. The Science of the Total Environment, 407(6), 1990-1997. http://dx.doi.org/10.1016/j.scitotenv.2008.11.021

Lévesque, B., Duchesne, J.-F., Gingras, S., Lavoie, R., Prud'Homme, D., Bernard, E., ... Ernst, P. (2006). The determinants of prevalence of health complaints among young competitive swimmers. International Archives of Occupational and Environmental Health, 80(1), 32-39. http://dx.doi.org/10.1007/s00420006-0100-0

Li, J., \& Blatchley, E. R. (2007). Volatile Disinfection Byproduct Formation Resulting from Chlorination of Organic-Nitrogen Precursors in Swimming Pools. Environmental Science \& Technology, 41(19), 6732-6739. http://dx.doi.org/10.1021/es070871

Lin, T. F., \& Hoang, S. W. (2000). Inhalation exposure to THMs from drinking water in south Taiwan. The Science of the Total Environment, 246(1), 41-49. http://dx.doi.org/10.1016/S0048-9697(99)00420-9

Maida, C. M., Di Benedetto, M. A., Firenze, A., Calamusa, G., Di Piazza, F., Milici, M. E., \& Romano, N. (2008). [Surveillance of the sanitary conditions of a public swimming pool in the city of Palermo (Italy)]. Igiene E Sanità Pubblica, 64(5), 581-593. Retrieved from http://www.ncbi.nlm.nih.gov/pubmed/19188935 
Malek, C. (2012). Legionnaires warning over cleaning of swimming pools and AC in the UAE. Retrieved January 12, 2015 from http://www.thenational.ae/news/uae-news/health/legionnaires-warning-overcleaning-of-swimming-pools-and-ac-in-the-uae

Massin, N., Bohadana, A. B., Wild, P., Hery, M., Toamain, J. P., \& Hubert, G. (1998). Respiratory symptoms and bronchial responsiveness in lifeguards exposed to nitrogen trichloride in indoor swimming pools. Occupational and Environmental Medicine, 55(4), 258-263. http://dx.doi.org/10.1136/oem.55.4.258

McConnell, R., Berhane, K., Gilliland, F., London, S. J., Islam, T., Gauderman, W. J., ... Peters, J. M. (2002). Asthma in exercising children exposed to ozone: a cohort study. Lancet, 359(9304), 386-391. http://dx.doi.org/10.1016/S0140-6736(02)07597-9

Medina-Ramón, M., Zock, J. P., Kogevinas, M., Sunyer, J., Torralba, Y., Borrell, A., ... Antó, J. M. (2005). Asthma, chronic bronchitis, and exposure to irritant agents in occupational domestic cleaning: a nested case-control study. Occupational and Environmental Medicine, 62(9), 598-606. http://dx.doi.org/10.1136/ oem.2004.017640

Meek, M. E., Beauchamp, R., Long, G., Moir, D., Turner, L., \& Walker, M. (2002). Chloroform: exposure estimation, hazard characterization, and exposure-response analysis. Journal of Toxicology and Environmental Health. Part B, Critical Reviews, 5(3), 283-334. http://dx.doi.org/10.1080/10937400 290070080

Nemery, B., Hoet, P. H. M., \& Nowak, D. (2002). Indoor swimming pools, water chlorination and respiratory health. European Respiratory Journal, 19(5), 790-793. http://dx.doi.org/10.1183/09031936.02.00308602

Parimon, T., Kanne, J. P., \& Pierson, D. J. (2004). Acute inhalation injury with evidence of diffuse bronchiolitis following chlorine gas exposure at a swimming pool. Respiratory Care, 49(3), 291-294. Retrieved from http://www.ncbi.nlm.nih.gov/pubmed/14982650

Potts, J. (1996). Factors associated with respiratory problems in swimmers. Sports Medicine (Auckland, N.Z.), 21(4), 256-261. http://dx.doi.org/10.2165/00007256-199621040-00002

Richardson, S. D., DeMarini, D. M., Kogevinas, M., Fernandez, P., Marco, E., Lourencetti, C., ... Villanueva, C. M. (2010). What's in the pool? A comprehensive identification of disinfection by-products and assessment of mutagenicity of chlorinated and brominated swimming pool water. Environmental Health Perspectives, 118(11), 1523-1530. doi:10.1289/ehp.1001965

Rumchev, K., Spickett, J., Bulsara, M., Phillips, M., \& Stick, S. (2004). Association of domestic exposure to volatile organic compounds with asthma in young children. Thorax, 59(9), 746-751. http://dx.doi.org/10.1136/thx.2003.013680

Rutala, W. A., \& Weber, D. J. (1997). Uses of inorganic hypochlorite (bleach) in health-care facilities. Clinical Microbiology Reviews, 10(4), 597-610. Retrieved from http://www.pubmedcentral.nih.gov/articlerender. fcgi? artid $=172936 \&$ tool $=$ pmcentrez\&rendertype $=$ abstract

Saberi, M. (2012). Don't just blame water for hair loss. Retrieved January 12, 2015, from http://gulfnews.com/news/gulf/uae/health/don-t-just-blame-water-for-hair-loss-1.1008506.

Sankar, A. (2009). Is the water in the swimming pool clean? Retrieved January 12, 2015, from http://gulfnews.com/news/gulf/uae/general/is-the-water-in-the-swimming-pool-clean-1.494107.

Saunders, M., Lewis, P. \& Thornhill, A. (2003). Research Methods for Business Students (4th ed.). Harlow: Prentice Hall.

Sherriff, A., Farrow, A., Golding, J., \& Henderson, J. (2005). Frequent use of chemical household products is associated with persistent wheezing in pre-school age children. Thorax, 60(1), 45-49. http://dx.doi.org/10.1136/thx.2004.021154

Shulaw, W., \& Bowman, G. (2001). Disinfection in on-farm biosecurity procedures. The Ohio State University Extension Fact Sheet VME-8-2001.

Takizawa, H. (2005). Bronchial epithelial cells in allergic reactions. Current Drug Targets. Inflammation and Allergy, 4(3), 305-311. Retrieved from http://www.ncbi.nlm.nih.gov/pubmed/16101538

The Regulation and Supervision Bureau. (2014). The Water Quality Regulations (4th ed.). Retrieved January 12, 2015, from http://rsb.gov.ae/assets/documents/366/regswaterquality4thedition.pdf

Thickett, K. M., McCoach, J. S., Gerber, J. M., Sadhra, S., \& Burge, P. S. (2002). Occupational asthma caused 
by chloramines in indoor swimming-pool air. The European Respiratory Journal, 19(5), 827-832. http://dx.doi.org/10.1183/09031936.02.00232802

Tulić, M. K., \& Hamid, Q. (2003). Contribution of the distal lung to the pathologic and physiologic changes in asthma: potential therapeutic target Roger S. Mitchell lecture. Chest, 123(3 Suppl), 348S-55S. http://dx.doi.org/10.1378/chest.123.3_suppl.348S

Villanueva, C. M., Cantor, K. P., Grimalt, J. O., Malats, N., Silverman, D., Tardon, A., ... Kogevinas, M. (2007). Bladder cancer and exposure to water disinfection by-products through ingestion, bathing, showering, and swimming in pools. American Journal of Epidemiology, 165(2), 148-156. http://dx.doi.org/10.1093/ aje/kwj364

Villanueva, C. M., Fernandez, F., Malats, N., Grimalt, J., \& Kogevinas, M. (2003). Meta-analysis of studies on individual consumption of chlorinated drinking water and bladder cancer. Journal of Epidemiology \& Community Health, 57(3), 166-173. http://dx.doi.org/10.1136/jech.57.3.166

Vohra, R., \& Clark, R. F. (2006). Chlorine-related inhalation injury from a swimming pool disinfectant in a 9-year-old girl. Pediatric Emergency Care, 22(4), 254-257. http://dx.doi.org/10.1097/01.pec.000021 0173.56010.c1

Voisin, C., Sardella, A., Marcucci, F., \& Bernard, A. (2010). Infant swimming in chlorinated pools and the risks of bronchiolitis, asthma and allergy. The European Respiratory Journal, 36(1), 41-47. http://dx.doi.org/10. 1183/09031936.00118009

Von Mutius, E. (2001). Is asthma really related to atopy?. Clin. Exp. Allergy, 31, 1651-1652.

Weaver, W. A., Li, J., Wen, Y., Johnston, J., Blatchley, M. R., \& Blatchley, E. R. (2009). Volatile disinfection by-product analysis from chlorinated indoor swimming pools. Water Research, 43(13), 3308-3318. http://dx.doi.org/10.1016/j.watres.2009.04.035

Weisel, C. P., Richardson, S. D., Nemery, B., Aggazzotti, G., Baraldi, E., Blatchley, E. R., ... Sattar, S. A. (2009). Childhood asthma and environmental exposures at swimming pools: state of the science and research recommendations. Environmental Health Perspectives, 117(4), 500-507. http://dx.doi.org/10.1289/ehp. 11513

Weng, S.-C., Weaver, W. A., Afifi, M. Z., Blatchley, T. N., Cramer, J. S., Chen, J., \& Blatchley, E. R. (2011). Dynamics of gas-phase trichloramine $(\mathrm{NCl} 3)$ in chlorinated, indoor swimming pool facilities. Indoor Air, 21(5), 391-399. http://dx.doi.org/10.1111/j.1600-0668.2011.00710.x

WHO. (2000). Environmental Health Criteria 216.Disinfectants and disinfectant by-products. International Programme on Chemical Safety.

WHO. (2004). Guidelines for drinking-water quality. In Vol 1. Recommendations. Geneva: World Health Organization.

WHO. (2006). Guidelines for Safe Recreational Water Environments. In Volume 2: Swimming Pools and Similar Environments. Geneva, Switzerland: WHO.

WHO. (2011). Guidelines for drinking-water quality (4th ed.). Geneva: External Web Site Icon World Health Organization.

Zock, J.-P., Plana, E., Jarvis, D., Antó, J. M., Kromhout, H., Kennedy, S. M., ... Kogevinas, M. (2007). The use of household cleaning sprays and adult asthma: an international longitudinal study. American Journal of Respiratory and Critical Care Medicine, 176(8), 735-741. http://dx.doi.org/10.1164/rccm.200612-1793OC

Zwick, H., Popp, W., Budik, G., Wanke, T., \& Rauscher, H. (1990). Increased sensitization to aeroallergens in competitive swimmers. Lung, 168(2), 111-115. http://dx.doi.org/10.1007/BF02719681.

\section{Copyrights}

Copyright for this article is retained by the author(s), with first publication rights granted to the journal.

This is an open-access article distributed under the terms and conditions of the Creative Commons Attribution license (http://creativecommons.org/licenses/by/3.0/). 